Portland State University

PDXScholar

2016

\title{
"Like a Parasite Dozing in the Gut": Idleness and Tending in J.M. Coetzee's Life and Times of Michael \\ $\mathrm{K}$
}

Patrick Barrett

Portland State University

Follow this and additional works at: https://pdxscholar.library.pdx.edu/honorstheses

Let us know how access to this document benefits you.

\section{Recommended Citation}

Barrett, Patrick, "'Like a Parasite Dozing in the Gut": Idleness and Tending in J.M. Coetzee's Life and Times of Michael K" (2016). University Honors Theses. Paper 329.

https://doi.org/10.15760/honors.278

This Thesis is brought to you for free and open access. It has been accepted for inclusion in University Honors Theses by an authorized administrator of PDXScholar. Please contact us if we can make this document more accessible: pdxscholar@pdx.edu. 
"Like a Parasite Dozing in the Gut": Idleness and Tending in J.M. Coetzee's Life and Times of

\title{
Michael K
}

by

\section{Patrick Barrett}

An undergraduate honors thesis submitted in partial fulfillment of the

\author{
requirements for the degree of \\ Bachelor of Arts \\ in \\ University Honors \\ and \\ English
}

Thesis Adviser

Bishupal Limbu

Portland State University 
“. . in our society where leisure is the rule, idleness is a sort of deviation." -Michel Foucault, "Of Other Spaces"

This paper will attempt to articulate how idleness functions in J.M. Coetzee's 1983 novel Life and Times of Michael $K$, and to analyze how it might be undermining or commenting on the idea of idleness which was discursively produced in South Africa in the 17th and 18th centuries. Coetzee develops a commentary on the European representation of idleness in his book White Writing: On the Culture of Letters in South Africa, which for my purposes will serve as a jumping off point for a reading of Michael K. Furthermore, I will seek to examine the ways in which idleness does not necessarily stand by itself, but in fact signals a broader modality of living enacted by the novel's titular character. In Life and Times of Michael K, idleness constitutes a mode of being which resists thinking of the future as an imaginative repository for the generational transmission of property and destabilizes a narrative of progress achieved through work. The figure of Michael K embodies not only idleness but also a form of tending which engages in a similar type of destabilization, as it too undermines the establishment of property.

In White Writing, Coetzee interrogates the discourse produced by European settler-colonialists in their attempt to understand and conceptualize South African people and landscape from the 17th century onward. Through an examination of the distinctly European ideas of "Man," cultural and historical linear teleology, naturalized conceptions of biological race, as well as the white artist's attempt at a harmonious relationship with landscape, Coetzee shows how and why certain generic traits of "white writing" have been produced. My purpose in 
examining such ideas here will be to attempt to understand Coetzee's analysis of the discursive production of certain Eurocentric ideas which are then represented in South African literature. Idleness specifically is a characteristic which follows a progression of being seen and recorded, subsequently disseminated in the form of writing, and finally taken as natural fact. Coetzee's consideration of idleness traces the reasoning behind such anthropological portraits, as well as their textual reproduction in the form of travel writing as well as colonial accounts of settling.

It will be useful first to consider the connotations of the word "idleness." According to the Oxford English Dictionary, one of the meanings of "idle" is to be "void of any real worth, usefulness, or significance; leading to no solid result." To be idle is also to be lazy, or in a state of un-work. Idleness is thus constituted by an absence of purpose, utility, and ends. To be idle is to resist telos ${ }^{1}$, remaining stagnant in a narrative which should be moving forward. Coetzee cites Jean Jacques Rousseau's Discourse on the Origin of Inequality as a particular iteration of Enlightenment thinking, in that it purports the distinction between leisure and idleness. According to Rousseau, Coetzee writes, "man is lifted out of primitive savagery by the invention of tools," in turn affording him leisure time in which "he begins to create conveniences for himself, conveniences which eventually develop into the yoke of civilization" (24). Rousseau believed so-called "Man" was meant to stay in this state, for after it came nothing but the “"decrepitude of the species"” (24). However, Coetzee writes, the "Hottentot"2 remained outside

\footnotetext{
${ }^{1}$ I take my definition of "telos" from the $O E D$ as well, which defines it as "End, purpose, ultimate object or aim." Telelogy is then such a focus on ends or objects. A teleological narrative, for my purposes, is one which moves in linear progression towards such an ultimate aim.

${ }^{2}$ Coetzee writes: "In accord with old-time usage, the usage of almost all the writers I deal with in this book, I employ the words Hottentot and Bushman instead of the modern Khoi and San. For the same reason, I sometimes use Kaffir for Xhosa and Boer for Afrikaner" (1). I've chosen to place both "Hottentot" and "Boer" in quotations so as to indicate their outdated status.
} 
of even this prelapsarian state, and subsequently the teleology of "Anthropological Man," mainly due to his idleness: "Idleness holds no promise save that of stasis" (25). Leisure, in this sense, can be seen as free time earned through the forging of tools, and is therefore valued as being morally preferable to idleness. The crucial point in this formulation proposed by Rousseau is the clear distinction between leisure and idleness. Leisure is a part of the general structure of work insofar as it is earned only through the process of labor. It subsequently allows for time to develop the means which will facilitate more work. Idleness, however, as Coetzee notes, is static, and contributes nothing to the forward progression of "Man" into a state of civilization.

How, then, might this idleness be related to the broader colonial project of settlement or the establishment of property in South Africa? One answer is the particular way in which the property was seen to be claimed through the work of cultivation in the Cape. In South Africa, imperialistic endeavors to appropriate land were rationalized by an ideology which claimed rights through cultivation. "In the theory of 'double right'3 propounded by Governor John Winthrop of Massachusetts, the rights of cultivators, who clear and settle the land, always take precedence over the rights of nomads, who merely hunt over it" (3). Here, property is appropriable through a certain type of contact with the earth, one which establishes ownership through cultivation and rights through a certain kind of emplacement, rather than a passing-through or -over. One could call this type of cultivation performative in that the act of clearing and settling brings into being property, and with it, hierarchy.

But there was not always a continuity from theory to practice in the colony: "Again and again visitors to the new colony warned that, from lack of any spur to activity in the

\footnotetext{
${ }^{3}$ Here, Coetzee cites Tichi, Cecilia. New World, New Earth. New Haven: Yale University Press. 1979.

Winthrop argued that the "double right" is both a natural right and a civil right to settle land, bestowed to humans by God.
} 
economically stagnant hinterland, colonists were declining in to the idle and brutish state of the Hottentots" (3). The supposed danger here is that of the "Boers" slowly becoming more similar to the "Hottentot," precisely because of their perceived idleness. This similitude would indicate, as Coetzee says, a more "brutish state," and therefore a self-removal from the timeline of "Anthropological Man," an idea which Coetzee cites as being central to Western European thought. I will examine this idea of "Man" in more detail below, but one central aspect in Coetzee's analysis here is the failure of the European to perform settlement properly. The lack of any work-based productivism indicated to "visitors" a slide into idleness, which they saw as one of the inherent characteristics of Africans in the Cape (25).

The "Discourse of the Cape," which incorporates ideas such as "Anthropological Man," is for Coetzee characterized by an account of differences between early travel writers or colonists, and the natives of South Africa. These differences were consistently noted in various logs and journals, often in list-form. Yet, while Coetzee notes the preponderance of supposed "differences between the Hottentot and ... the Western European as he imagined himself to be," these differences were situated "within a framework of samenesses," a framework constituted by the simple idea that "they [the 'Hottentots'] are in fact men" (13). The simple fact of being human meant there were universals accounted for between the settlers and the natives, "while particular observations inserted in the various slots will constitute the differentia that mark particular societies." Coetzee complicates the idea of these being mere day-to-day descriptions by noting that they are "a series of sightings and observations selected from sense-data only on the grounds that they are striking, remarkable; that is to say ... [they constitute] a mere narrative rather than a comprehensive description" (15). Idleness is one such difference which makes up a 
component part in this larger narrative, and after 1652 was consistently referenced as a defining characteristic of the "Hottentot" lifestyle, from the obviously Eurocentric point of view of the settler (18).

Idleness is then an anthropological description which places both the "Hottentot" and "Boer" at risk of being outside of the forward moving narrative of European thought constituted both by the timeline of "Anthropological Man" as well as the establishment and continuation of property. As stated above, if it is interrupting, troubling, or undermining the "double right" purported by Winthrop, the perceived performance of idleness on the part of settlers is indicative of the European engaging with the land in the wrong way. However, this idleness has different implications for both Europeans and Africans. Coetzee notes that "Boer" idleness is distinguished from that of the "Hottentot" for various reasons, one being that it is "achieved at the expense of the misery of slaves and servants" (31). Therefore, whatever idleness signals depends on who is enacting it: if the "Hottentots" are idle, they are "underdeveloped" (22); if the "Boers" are idle, they are in a process of regression, moving backwards into such a state of underdevelopment (30). The supposed idleness of the "Boers" was observed by British colonists as indicative of this regression, but was doubly frowned upon because of its dependence on the aforementioned slave labor of the indigenous population.

When it came time to represent the idealized idle farm life aesthetically, however, the South African artists came up against a double-bind: "To satisfy the critics of rural retreat, it [the artistic representation] must portray labour; to satisfy the critics of colonialism, it must portray white labour" (5). What followed was the occlusion of black labor from representations of the Afrikaner farm, which also signified the artistic landscape's relationship to property: "If the work 
of hands on a particular patch of earth, digging, ploughing, planting, building, is what inscribes it as the property of its occupiers by right, then the hands of black serfs doing the work had better not be seen." Coetzee is then arguing that the work of settling is also the work of writing: inscription signifies possession of property, and in a sense cordons off otherwise open space. Black labor, in this sense, must not be depicted within the genre, because doing so would indicate an ability to inscribe, and, as stated above, claim property. Coetzee argues that this writerly attempt at the conservation of a "rural order" constitutes a "dream topography," which "projects . . a network of boundaries crisscrossing the surface of the land" (6).

However, this "dream topography" is contested by another: "South Africa as a vast, empty, silent space ..." (7). Here, "the task of the human imagination is to conceive not a social order capable of domesticating the landscape, but any kind of relation at all that consciousness can have with it." In this other "dream topography," the landscape is not perceived as one which can be easily settled by tilling the land because it is rendered not as fertile but one of "rock and sun," making it impervious to cultivation. In turn, this conceptualization of the land does not lend itself to inscription as property-making. The writer struggles to find the "consciousness" with which to engage the landscape of South Africa, and "this landscape remains alien, impenetrable, until a language is found in which to win it, speak it, represent it." The language the white writer is endowed with is then inadequate in addressing the land. Yet it would seem that this attempt to search for a new language which supplements the rupture between poet and landscape is itself at least an attempt at inscription.

Coetzee argues this becomes a matter of a certain structure of poetic address, one constituted by a dialogical interaction: "In the words he [the poet] throws out to the landscape, in 
the echoes he listens for, he is seeking a dialogue with Africa, a reciprocity with Africa, that will allow him an identity better than that of visitor, stranger, transient" (8). What constitutes this dyadic encounter, however, is an address which is echoed back to the poet, so that the dialogue or reciprocal relationship becomes known only through the reverberation of what's been said. And while this address does not necessarily seek to inscribe the land with boundaries, with fenced-off farm land, it does seek out nativity, a certain right to be-in-place. The paradigms of "visitor, stranger, transient," laid out by Coetzee can easily be connected to the "nomad" subordinate to the settler who stakes out territory in the other "dream topography." In this equation the nomad passes over the land, while the settler writes it, digs into it, claims it as his own. These "unsettled settlers" (4) continually attempted to supplement a rupture embedded between their language and the landscape, between poetics and the idea of property.

The acts performed in each "dream topography" proposed by Coetzee indicate a desire to relate to the land in a certain way: the "network of boundaries" constituted by cultivation are an effect of property-making, and the address the poet enacts is a form of "capture" in order to "win it [the land], speak it, represent it" (7). It is my sense that this poetic "capture" is akin to the cultivation-as-inscription model embedded in the other "dream topography," in that Coetzee conceives of both as indicative of the desire to inscribe, and therefore place order on, the landscape. ${ }^{4}$ This ordering is a way of not only capturing but bringing the land or landscape into the future, for if the poet seeks to address the land in order to reserve a status superior to "visitor," it is due to the need to establish a solidified identity in order to combat the experience

\footnotetext{
${ }^{4}$ Barnard argues that this second "dream topography" is in fact one of erasure, in that instead of boundaries it projects blankness onto the landscape. While I agree with her point, I do find it notable that the language Coetzee uses with regard to the aims of the poet should be that of capture and representation. In this sense, while this other "dream topography" does not inscribe materially, it is imbued with a desire to represent, and therefore write.
} 
of being "unsettled." I am arguing that inherent in the act of settling is the generational succession of bounded land, meaning futurity becomes inextricable from any establishment of property. And if a defining characteristic of the proper settler is the establishment of property, and the "nomads" are defined precisely by their inability to enact such inscription, then it follows that idleness, representative of an improper mode of living, is more in line (at least in theory) with such a nomadic lifestyle.

Idleness can then be seen as disrupting numerous colonial enterprises and ideas: the proper mode of cultivating the land and the labor required to do so; the movement of "Anthropological Man" in its mode of teleological narrative which progresses from savagery to civilization; and, in a similar manner of narrative movement, the transmission of landed property into the future. As Rita Barnard notes, Life and Times of Michael $K$ was written around the same time as many of the essays in White Writing, and so the novel is concerned with many of these themes as well (Barnard 29). My aim in this reading of the novel is to explore Coetzee's staging of the complex interweaving of some of these ideas, particularly the status of idleness and its effects.

The plot of Life and Times of Michael K can be (reductively) summarized as follows. Michael is a gardener who works at a city park in Cape Town, South Africa. His mother, Anna $\mathrm{K}$, her health in decline, devises a plan to leave the city and return to the place of her birth in the district of Prince Albert. Complications with obtaining a permit to leave the city result in Michael constructing a cart with which to transport her, and the two leave Cape Town-Michael on foot, his mother in the barrow. Anna's health deteriorates by the time they reach Stellenbosch, and she dies after being hospitalized. $\mathrm{K}$ sets out from there, and at the outskirts of Worcester 
encounters a military roadblock, is put on a train, forced to clear the aftermath of a landslide from the tracks, and is subsequently let go. After reaching Prince Albert, K seeks out the farm his mother grew up on, and is sent to an unoccupied property owned by a family with the surname Visagie. It is here he begins his "life as a cultivator" after scattering his mother's ashes (59). However, eventually the Visagies' grandson arrives and attempts to subjugate $\mathrm{K}$ by taking him on as his employee. $\mathrm{K}$ leaves for the mountains, spends time there (mostly in idleness), and eventually heads back into town, where he is again arrested. It is at this point in the book we are told of his categorization within the apartheid system: " $\mathrm{CM}$ ['coloured male'] $-40-\mathrm{NFA}$ ['no fixed abode']—Unemployed" (70). This time, he is taken to a work camp, Jakkalsdrif, where he is made to labor for farms in the surrounding area. He escapes the camp and returns to the Visagie farm, which has apparently been abandoned by the grandson. It is at this point in the novel that $\mathrm{K}$ builds a shelter and begins tending a garden of pumpkins. After a while he is discovered by soldiers and is arrested for the last time. From here he is taken to a medical camp, and the narration turns to a first person account from a medical officer who is K's caretaker. K escapes this camp, too, and returns to Cape Town, where the novel ends. The reader will note the consistent evasion of camps, a central theme in the text, as well as the significant amount of movement and travel $\mathrm{K}$ undertakes in order to maintain such fugitivity. For my purposes, the plot points of the novel which will be central to my reading occur when $\mathrm{K}$ is positioned on the farm, tending to his garden, and in the work camp, both contemplating and resisting the idea of work. While the novel could perhaps be read as taking place at an ambiguous point in South Africa's history, it is almost always read as a story set in a projected future from the time Coetzee is writing in (early 1980's), depicting the logical outcome of a continued repressive 
apartheid state wherein there is an organized rebellion and the national government has enacted a heightened state of violence and containment, as indicated by the work and relocation camps. In the collection of interviews and essays Doubling the Point, Coetzee himself writes, "To a reader taking this line [one of asserting a need for a 'less spineless hero'], much of the text of Michael $\mathrm{K}$ is just one fancy evasion after another of an overriding political question: how shall the tyranny of apartheid be ended (207)?" My point here is not to support or contrast my own reading of the novel with the one proposed above, or Coetzee's reflection on the novel's criticisms, but rather to demonstrate that situating Michael $K$ as an apartheid story has been crucial to many readings of the novel, and so this paper will assume such is the historical positioning of the text.

Coetzee reorients the idea of idleness in Life and Times of Michael $K$ through the titular character's particular mode of living. In White Writing, Coetzee sees idleness as posing a "challenge ... to work ... [a] power to scandalize" (34). Similarly, in Michael K it is not taken for granted to be a stable, natural state of being, as the anthropological lens of the European settler or traveler would have it, but is instead performed in relation to a work-driven mode of production. This productivity relies upon the opposition between work and leisure, as in the case of the Enlightenment philosophy Coetzee points to in White Writing. Rather than rendering it as a trait seen to be natural by the colonial eye, Coetzee contextualizes idleness in Michael K by staging it as a challenge to power. In other words, idleness is not necessarily taken up by $\mathrm{K}$ due to a natural predisposition for doing so, but is instead performed in reaction to a state which violently represses vagrancy with forced labor and spatial fixity. ${ }^{5}$ Barnard has pointed to a

\footnotetext{
${ }^{5}$ Here the idea of fixity can be related to the above mentioned apartheid categorization of $\mathrm{K}$ as having "NFA," or "no fixed abode."
} 
particular passage in the novel wherein K contemplates the "times like these" which have led him to live as he does as demonstrating how K's actions are always in reaction to and against an apartheid state ( $M K$ 99, Barnard 25). In the novel, idleness is punishable because it stands askance from the opposition of work and leisure, while at the same time being intimately caught up in it through the persistent disruption and subversion it enacts.

If the Eurocentric vision of work on the farm is one which inscribes the land, a mode of living which disregards the very idea of work as such tends to the land while avoiding the same type of inscription as the establishment of boundaries. This is not to say the mode of tending taken up by $\mathrm{K}$ is not inscription. Rather, it is inscription of a different kind. The settler colonial mode of cultivation as inscription and in turn, property-making, constitutes a certain type of address - one which sees space as appropriable, fungible, and subject to exploitation and commodification. By casting a character such as $\mathrm{K}$ who engages in a mode of tending which avoids such traps, and by using the language of idleness and vagrancy to flesh out K's way of life in the story, Coetzee's narrative reorients ideas which were discursively produced about "Hottentots" and "Boers," originally intended to categorize, differentiate, and discipline them. Idleness, at first seen by the European Christian colonists as a character flaw, one which Afrikaner farmers were susceptible to sliding into, becomes a way of being taken up in reaction to a violent apartheid state fixated on moving into the future with the idea of work (and its counterpart, leisure) fully stabilized.

The word "idleness" itself is used explicitly at two particular points in the novel, one of which comes after $\mathrm{K}$ escapes from Jakkalsdrif and returns to the Visagie farm, sets up his shelter, 
and plants his pumpkin seeds. $\mathrm{K}$ is described as becoming a "creature of twilight and "learning to love idleness," Coetzee writes,

idleness no longer as stretches of freedom reclaimed by stealth here and there from involuntary labor, surreptitious thefts to be enjoyed sitting on his heels before a flowerbed with the fork dangling from his fingers, but as a yielding up of himself to time, to a time flowing slowly like oil from horizon to horizon over the face of the world ... (MK 115)

Previously, in his days as a gardener employed by the state, K experienced a structured time which was discontinuous and fragmented into "stretches" that needed to be (re)possessed. Time was appropriated recessively through the extraction of moments from a day which could otherwise be used for work. Here, time is surrendered to and rid of its connections to "involuntary labor," "surreptitious theft" and "stealth." At this particular moment in the novel time is no longer moving straight ahead in an arrow-like manner, but is rather pervading the world in a non-linear "flowing" movement. It should be noted too that implicit in this passage is the sundering of time and property: time is no longer an object which $\mathrm{K}$ must steal and relish in secret. Rather, it is a permeating force which is experienced in totality. $\mathrm{K}$ is now able to be as useless as he pleases, unconcerned with the the imposition of results. The temporality explicitly represented in this passage resists the teleological narrative of progress ${ }^{6}$ : time is moving "onward" and taking K with it, but it is a completely separate time, as evidenced by his distinction between "the other time" of the war state, and his own world, in which time is not indicated by the image of the rapid movement of a fighter jet, but a slow oozing oil (115-6). K is then positioned as motionless inside of time, and subsequently outside of any progression into

\footnotetext{
${ }^{6}$ In this sense, a narrative laid out in linear time would always have telos driving its forward moving progression. This idea is related to the narrative of "Anthropological Man" Coetzee analyzes in White Writing, inherent in which is "the idea that cultures can be ranged along a scale of evolutionary ascent from 'backward' to 'advanced.' (10). My argument suggests that idleness is one way in which such a narrative is troubled, through its very enactment of stasis.
} 
the future. K's time on the farm allows for such idleness to take place, and idleness then serves as the condition of possibility for the experience of such a non-linear temporality.

This idleness, this movement towards nothing in particular-what the $O E D$ would have as "void of any real worth" - is achieved without hindrance at the farm $\mathrm{K}$ is living upon. The work camp, however, provides more of an obstacle. Jakkalsdrif, the camp in which $\mathrm{K}$ is detained, serves as a site for the extraction of labor by the surrounding areas. Robert, another man in the at Jakkalsdrif, answers the question of who is in favor of the camp as follows: "The Railways would like to half a Jakkalsdrif every ten miles along the line. Second, the farmers. Because from a gang from Jakkalsdrif a farmer gets a day's work blood cheap, and at the end of the day the truck fetches them and they are gone..." ( $M K 82)$. The labor extracted from the camp is then acquired for a low price, but is also mobile and easily made invisible by the fact of their mobility. Jakkalsdrif is therefore a reservoir of extractable and removable labor.

When $\mathrm{K}$ is detained, he resists the demands of those trying to utilize his labor by staying at the camp while the rest of the men are transported to the site of work. After being warned he will not be paid, "K brought his mattress out and lay next to the hut in the shade with an arm over his face while the camp lived its life around him” ( $M K$ 84). Again, we get a representation of $\mathrm{K}$ as being outside the time of others. He performs this idleness within a space designed to "teach lazy people to work" (91), and avoids the work he does not want to do, but however unknowingly also enacts what Coetzee calls the "challenge of idleness to work, its power to scandalize" $(W W 34)$. Here a connection can be drawn to a point in the novel when $\mathrm{K}$ is explicitly referred to as scandalous by the officer overseeing his stay at the medical camp. The officer calls K's stay an "allegory ... of how scandalously, how outrageously a meaning can 
take up residence in a system without becoming a term in it" (166). The reference here seems to be linguistic — the idea that $\mathrm{K}$ is a "signifier that escapes systematization" — but we can relate this back to his position as an idle body in Jakkalsdrif as well. K does "take up residence" in the "system" of the camp, but avoids its attempts to fix him — both meanings of the word "fix" being evoked. However, after attempting to lie in his bed instead of work, the next morning he is forced to go with the others on the labor call, and his brief attempt at idleness is thwarted. The problem with K's behavior in the context of the camp seems to stem less from the act of lying down than the mere fact that he is not using his body toward a certain purpose - namely, farm work and building fences. ${ }^{8}$

Coetzee argues that work can be thought of as an idea which manifests at certain points in time, for example in the move "from pastoralism to agriculture" ( $W W 34)$. Work as an historically specific idea could be conceptualized as stemming from a desire to produce more, with the idea of work as morally good coming out of the perceived necessity and value of this labor. Work then comes to be understood as virtuous because it moves society into the future by way of a narrative of progress, accumulation, and reproduction. In this sense, idleness is not only looked down upon for moral or theological reasons, but also for the fact that it directly disrupts the intended flow of labor provided by the camp. If Coetzee is staging South African apartheid taken to its logical conclusion in the form of all-out war, then the camp comes to represent a place in which the components necessary for the continuation of that war are maintained, one of

\footnotetext{
${ }^{7}$ Attridge, Derek. J.M. Coetzee and the Ethics of Reading: Literature in the Event. Chicago: University of Chicago Press. 2004. Pg. 49.

${ }^{8}$ Fences are a recurrent theme throughout the novel. In reading Michael $K$ alongside White Writing, this theme's presence can most likely be attributed to the first "dream topography" proposed by Coetzee, one which conceptualizes the landscape of South Africa as a "network of boundaries" (6).
} 
which, in this case, is a hidden labor force. K's idleness within the camp again serves to disrupt this function of labor and the temporality embedded within it.

The status of the camp is also examined specifically in relation to the town of Prince Albert. When $\mathrm{K}$ is on the farm, lying in idleness, he contemplates the police officer's use of the word "parasite" to describe the relationship between the town and the camp. The passage is worth quoting at length:

... a nest of parasites hanging from the neat sunlit town, eating its substance, giving no nourishment back. Yet to K lying idle in his bed, thinking without passion (What is it to me, after all? he thought), it was no longer obvious which was host and which parasite, camp or town. If the worm devoured the sheep, why did the sheep swallow the worm? What if there were millions, more millions than anyone knew, living in camps, living on alms, living off the land, living by guile, creeping away in corners to escape the times, too canny to put out flags and draw attention to themselves and be counted? What if the hosts were far outnumbered by the parasites, the parasites of idleness and the other secret parasites in the army and the police force and the schools and factories and offices, the parasites of the heart? Parasites too had flesh and substance; parasites too could be preyed upon. Perhaps in truth whether the camp was declared a parasite on the town or the town on the camp depended on no more than who made his voice heard loudest. (116)

The self-reflective question, "What is to me, after all?" signals the ethical distance enabled by K's idleness. In other words, it is K "lying idle in his bed" that allows him to position himself outside of the cares and concerns of the opposition between the camp and the town. The common sense belief that parasites do the work of draining the energy of its host without giving any back comes under question in the realization that it is in fact the host which has received the parasite in the first place. The inversion of this paradigm is furthered by the consideration of scale: if parasites are believed to be marginal, what happens after the realization that so-called parasites are in fact everywhere, and are just as integral to society as the host? The very suggestion at the potential that the town is a parasite "on the camp" hints at the role Jakkalsdrif and other camps 
like it play in the structure South African society as it is represented in the novel. The town considers itself superior, constantly burdened by the mere presence of the camp. K's friend Robert speculates the people of the town "would really like ... for the camp to be miles away in the middle of the Koup out of sight. Then we could come on tiptoe in the middle of the night like fairies and do their work, dig their gardens ...” (MK 82). The town depends on the camp for labor, yet wishes for its erasure at the very same time. Robert's comments echo questions posed by Coetzee in White Writing concerning the attempts within the South African pastoral genre to occlude black labor: "Do white hands truly pick the fruit, reap the grain, milk the cows, shear the sheep in these bucolic retreats" (11)? The answer, in the case of the novel-if we are to glean anything from the meditation on the parasite/host dichotomy—is decidedly "no."

If in the camp $\mathrm{K}$ is undermining the progress of the extraction of labor, on the farm the very idea of work itself is destabilized. In the same passage which finds K "learning to love idleness," work becomes assimilated to the rest of his activities:

He was neither please nor displeased when there was work to do; it was all the same. He could lie all afternoon with his eyes open, staring at the corrugations in the roof-iron and the tracings of rust; his mind would not wander, he would see nothing but the iron, the lines would not transform themselves into pattern or fantasy; he was himself, lying in his own house, the rust was merely rust, all that was moving was time, bearing him onward in its flow. (115)

Work is then a source of neither inconvenience nor pleasure, which in turn severs virtue from labor. Subsequently, we might say this furthers the resistance to the extraction of labor, something a camp such as Jakkalsdrif relies upon. The very act of work itself is no longer work, as it is "all the same," and it is therefore impossible to distinguish free time from work. Here it will be useful to draw a connection to The Culture Industry by Theodor Adorno, who argues that the "human condition which sees itself as the opposite of reification, the oasis of unmediated life 
within a completely mediated total system, has itself been reified just like the distinction between labour and free time. The latter is a continuation of the forms of profit-oriented social life" (189). What is thought to be "free" is in fact inextricable from the forms of profit it originally sought to define itself against. Is $\mathrm{K}$ then removing himself from the opposition of work and free time, given that both are caught up in a system of profit? We might say that idleness, or a form of living which facilitates it, embodies the resistance to any sort of "profit-oriented social life." In this way, the idea of profit is interconnected with that of teleology, as both seem to be constituted a narrative movement of forward progression.

I am not interested in K's idle moments solely for their own sake, but rather wish to show how they indicate Coetzee staging a type of non-productivity which resists both the fixity others attempt to place on him as well as a movement into the future which would seek to progress toward a clear and defined resolution. It will also be useful to attend to moments in the book which do not find $\mathrm{K}$ being idle, for they too operate on a similar level. The novel indeed illustrates a character who travels a great distance, labors (many times under threat of punishment/unemployment), and tends to his garden. What is the connection, then, between moments of idleness and those which find $\mathrm{K}$ engaging in purposeful acts of tending?

K's character is in part defined by his status as a gardener: before leaving for the countryside with his mother, he works for the city at De Waal Park as a "Gardener, grade 1" (MK 4). This role is precisely one which forces $\mathrm{K}$ to think of free time as "surreptitious thefts" (115). As I have argued earlier, this form of labor seems to entail a representation of time as fragmented, linear, and appropriable. The same passage represents the time of the farm as pervasive, flowing, and non-linear, as experienced when $\mathrm{K}$ is "yielding up" to time. This 
temporality, characterized by the disavowal of linearity, is also related to how $\mathrm{K}$ sees his existence as a "cultivator" (59) on the farm. The moment when K turns to being a "cultivator" rather than a "gardener" is significant, as it is marked by the placement of his mother's ashes onto the earth. That a death and subsequent scattering of ashes would catalyze a life of cultivation seems to be indicative, again, of a cyclical temporality. The fact that he does not bury the ashes but instead "set[s] about clearing a patch a few metres square" to spread them upon points again to a mode of tending which takes place over or on the earth, rather than materially inscribing it and marking it as property.

K's transition from "Gardener, grade 1" to "cultivator" begins to take shape as he spends a greater amount of time on the Visagie farm. The manner in which he plants his pumpkin seeds is determined by his need to be invisible: "He no longer dared to irrigate the entire acre, for the greenness of new grass would betray him" (101). In other words, a field of well-watered grass would signal to passersby or anyone flying overhead that he is living there, thus putting him in immediate danger of being arrested again. So instead, "he watered the seeds one by one, carrying water from the dam in an old paint-tin." This kind of tending is careful and minimal: there is no need develop surplus agricultural product. In fact, in K's case, doing so might cause more harm than good. This minimalist attention to his crop is continued when the pumpkins are ready to eat, a moment in which $\mathrm{K}$ even contemplates his future: "Now it is completed, he said to himself. All that remains is to live here quietly for the rest of my life, eating the food that my own labour has made the earth to yield" (113). This proposed cycle of cultivating, tending, and subsisting is then imagined as carrying into the future. However, such a future is nevertheless void of the idea of land as property. 
K's time on the farm is characterized by an imperative to exist without a "trace of his living" (99). Interestingly, this tracelessness is rendered as a "pity" by K when he first returns to the farm from Jakkalsdrif. He thinks to himself, "A man must live so that he leaves no trace of his living. That is what it has come to." This is the same passage that describes the "times like these" which force $\mathrm{K}$ to live in such a way. However, as time passes, it seems as though $\mathrm{K}$ starts to see his mode of living on the farm less and less from a standpoint of "pity." Rather, he starts to craft an ethos of his own - always as a result of the social and political circumstances which have brought him to this point, but nevertheless seemingly void of any sorrow or grievance. We can see $\mathrm{K}$ developing his own sense of tending when he opts to avoid using the resources left by the Visagies on the farm:

But he was wary of conveying the Visagies' rubbish to his home in the earth and setting himself on a trail that might lead to the re-enactment of their misfortunes. The worst mistake, he told himself, would be to try to found a new house, a rival line, on his small beginnings out at the dam. Even his tools should be of wood and leather and gut, materials the insects would eat when one day he no longer needed them. (104)

Here $\mathrm{K}$ is hesitant to fall into the traps of the settler-colonial mode of life, namely the establishment of private property which will be cordoned off and handed down generationally. In the case of the Visagie farm, however, such a passing-on will only bring "misfortune." The very tools $\mathrm{K}$ wishes to use in the work of cultivation will themselves deteriorate, and therefore the work he intends to perform on the farm is in a consistent process of disappearance. Here Coetzee seems to again be setting up a clear distinction between cultivation which inscribes the land, marking property, and K's form of tending which could be said to inscribe through cultivation, but is different in that this inscription is also its own erasure. In this sense, K's tending is related to his idleness precisely through the stance towards the future which both of them enact: 
cultivation and tending ensure their own disappearance, therefore resisting permanence; idleness poses a challenge to the idea of work, and subsequently disrupts a linear movement of time which would facilitate the insurance of propertied land in the future.

$\mathrm{K}$ views the construction of his shelter out in the veld in a similar manner to that of his garden work. One passage indicative of K's ambivalence toward futurity, and therefore inscription, comes when he is contemplating the construction of his shelter:

I should have laid a bed of stones beneath the sand, he thought; and I should have allowed myself an eave. But then he thought: I am not building a house out here by the dam to pass on to other generations. What I make ought to be careless, makeshift, a shelter to be abandoned without a tugging at the heartstrings. So that if ever they find this place or its ruins, and shake their heads and say to each other: What shiftless creatures, how little pride they took in their work!, it will not matter. (101)

K's thought process seems to shift from a meditation on the merits of construction reliant upon solid foundations able to withstand time, to one which abandons the future as an imaginative repository for his creations. The future as imaginative repository would be constituted by the act of building a structure or establishing property with the intention of passing it on, which is precisely what $\mathrm{K}$ intends not to do. If the settler's property is one passed on to "children and grandchildren in perpetuity" (47), K's shelter becomes a site bearing the quality of disappearance which undermines that perpetuity. Here it should be noted that Coetzee is not staging this scene for the reader to glean an imperative to "leave no trace," as a modern environmentalist ethos might have it. Rather, $\mathrm{K}$ imagines this structure, or its ruins, still being in place when the imagined "they" discover it. In fact, it doesn't seem relevant whether the shelter is in "ruins" or not. More important to him is the very uselessness - the word "shiftless" "shares much in

\footnotetext{
${ }^{9} O E D$ : "Lacking in resource; incapable of shifting for oneself; hence, lazy, inefficient."
} 
common with "idle" —of the housing structure. This uselessness in turn resists the affect typically endowed to propertied spaces, such as the farm in the South African colonial settler imagination. In other words, what is being undermined is not just the stability of a future with property, but the "dream topography" — what Barnard might call "the Afrikaner novelist's patriarchal idyll" (29) — which is constituted by an imagining of the landscape as a space marked by boundaries.

As I have argued, the most crucial aspect of K's particular way of relating to the future is the idea that any trace $\mathrm{K}$ leaves behind is rudimentary, and its future is its own erasure. We can see this idea surface in another instance on the farm which portrays K working: “. . . as the sun set he would come out, stretch himself, and go down to the river-bed to chop wood till he could no longer see his mark" (114). Work becomes the very condition which facilitates disappearance, as the act of chopping wood becomes connected to the erasure of his "mark," a word which appears to stand in for "shadow." In contrast to a type of work which would settle land, mark off property, and carry on into the future, K's work here disappears more the longer it goes on. If this mode of living taken up by $\mathrm{K}$ is an inversion and destabilization of the settler colonial paradigm laid out by Coetzee in White Writing, what are we, as readers, to glean from the novel's representations of such an idle, seemingly traceless lifestyle? This is not to say that Michael K, or for that matter any novel, need be programmatic. Rather, I would speculate that given its setting in a highly politicized environment, it would seem to follow that any reading of the novel must also caught up in its perceived political implications.

Barnard argues that "The brilliance of the survival strategy Michael K devises is that he finds a way to reclaim displacement and tracklessness as a form of freedom. He turns the social 
condition prescribed for him — that of having to work the land without owning or inscribing it—into something else, something to be desired" (31). While I agree that Coetzee is staging a subversion of the codes examined in White Writing - indeed, my reading of K's idleness falls in line with such a reading - I question her use of the word "freedom" as an adequate way of describing what $\mathrm{K}$ achieves (if he achieves anything). True, the novel portrays him constantly evading camps, undermining authority by way of idleness and the recessive life he enacts on the farm. But if the strategies staged in the novel lead to its main character being back in Cape Town, the place he was trying to escape in the first place, and dreaming of going back to the farm while in actuality he is on the verge of death by starvation (a seemingly intentional starvation, but starvation nonetheless), are we to read this as "freedom," one which is "to be desired?" Furthermore, if the question posed by K's meditations on the spaces "between the fences" asks whether or not there is indeed life outside of the camp, in whatever form it may take, the answer remains elusive. Such a life would seem to require the constant evasion of authority, a mode of being which is represented in the novel as temporary and contingent. In other words, if K does experience "freedom," it is only temporarily unhibited. However, it remains questionable, to my mind, whether or not $\mathrm{K}$ ever truly lives outside of the structures of power seeking to keep him in a state of fixity. Barnard cites a passage in which $\mathrm{K}$ recalls his time at Huis Norenius, the school he attended in childhood, as being indicative of a "prefigured" reorientation of the effects of authority: "One of the teachers used to make his class sit with their hands on their heads, their lips pressed tightly together and their eyes closed, while he patrolled the rows with his long ruler. In time, to $\mathrm{K}$ the posture grew to lose its meaning as punishment and became an avenue of reverie" ( $M K$ 68). This passage represents $\mathrm{K}$ shifting the expected 
effects of something like discipline, and more broadly, apartheid, into "reverie." But the danger here, again, seems to lie in the romanticization of K's lifestyle as one "to be desired." This reading may even contradict the fact that $\mathrm{K}$ himself is a character who is constantly portrayed as absent of passion or desire. My sense is that rather than staging idleness and the other component parts of K's lifestyle as something to be desired, Coetzee is exploring what the outcomes of such a life might be if the dominant discourse is taken up and subverted. The results, as the end of novel shows, leave the reader with no clear answer as to whether or not K's positioning within the framework of apartheid is a politically or ethically feasible one.

Indeed, the political implications of the novel are further complicated by its ending. $\mathrm{K}$ winds up back in Cape Town after escaping yet another camp, ${ }^{10}$ and finds his mother's old room in the building where she had previously lived. The last lines of the novel are written in a future conditional tense, as $\mathrm{K}$ imagines himself and a companion, an old man, travelling back out into the country. $\mathrm{K}$ imagines a scene in which they contemplate what to do when they discover the pump at the dam on the Visagie farm has been "blown up" by soldiers. Coetzee writes,

he, Michael K, would produce a teaspoon from his pocket, a teaspoon and a long roll of string. He would clear the rubble from the mouth of the shaft, he would bend the handle of the teaspoon in a loop and tie the string to it, he would lower it down the shaft deep into the earth, and when he brought it up there would be water in the bowl of the spoon; and in that way, he would say, one can live. (184)

This scene recalls the minimal tending $\mathrm{K}$ engages in at his pumpkin garden- - the slow, careful transportation of water to the necessary patch of land. In fact, one of K's main regrets is that his

\footnotetext{
${ }^{10}$ After his time on the Visagie farm, $\mathrm{K}$ is detained at a medical camp. As mentioned in my brief summary of the novel, this section is narrated by a medical officer overseeing the general operations of the camp, who takes an interest in Michael, and sometimes addresses him directly, at one point in the form of a letter. This section seems to be invested questions of writing, narration, and representation, as well as the idea of misreading. While these ideas are worth unpacking in relation to the broader scope of the novel, there is not enough space in this paper for such a reading.
} 
garden did not cover even more ground: "I should have planted them one at a time spread out over miles of veld in patches of soil no larger than my hand, and drawn a map and kept it with me at all times so that every night I could make a tour of the sites to water them (183)." While the last paragraph of the novel is mostly written with the use of the modal verb "would," the last phrase is "one can live," offering more of an affirmation than the use of the modal "could." One reading might say that this passage is an attempt to bring us out of the failure which is occurring in the real time of the novel-in which $\mathrm{K}$ is slowly deteriorating in his mother's former dwelling - by introducing the imaginative making of what could be happening, if $\mathrm{K}$ were able to return to his life of idleness and gardening. Due to a world consisting of an overwhelming amount of camps, this imaginative faculty is perhaps one way in which $\mathrm{K}$ is able to sustain a life for himself in the space between fences. Again, it doesn't seem as though Coetzee stages this predicament in order to valorize idleness, or a tending which relies on disappearance. If $\mathrm{K}$ ends up back in Cape Town, then the novel has in fact staged their failure. But for him, being out of camps is "enough of an achievement, for the time being" (182), even if we the reader are constantly pushed to question the validity of this proposed space outside of property. 


\section{Works Cited}

Adorno, Theodor. The Culture Industry. London: Routledge. 2001. Print.

Barnard, Rita. Apartheid and Beyond: South African Writers and the Politics of Place. Oxford: Oxford University Press. 2007. Print.

Coetzee, J.M. Doubling the Point: Essays and Interviews. David Atwell, ed. Cambridge: Harvard University Press. 1992. Print.

---. Life and Times of Michael K. 1983. New York: Viking Penguin Inc., 1985. Print.

---. White Writing: On the Culture of Letters in South Africa. New Haven: Yale University Press. 1988. Print. 